\title{
PROPOSIÇÃO DE UM ROTEIRO GEOTURÍSTICO PARA O MUNICÍPIO DE SANTO ANTÔNIO DA PLATINA (PR) ${ }^{1}$
}

\section{PROPOSITION OF A GEOTUTISTIC SCRIPT TO THE SANTO ANTÔNIO DA PLATINA (PR) MUNICIPALITY}

\author{
Euzemar FLORENTINO JUNIOR ${ }^{2}$ \\ Gilnei MACHADO ${ }^{3}$
}

\begin{abstract}
Resumo: Esta pesquisa teve como objetivo levantar e caracterizar alguns elementos da Geodiversidade em Santo Antônio da Platina - PR, ao longo das rodovias PR - 439, PR - 092 e BR 153, para a elaboração de um roteiro geoturístico neste município. A elaboração envolveu três etapas procedimentais: pesquisa bibliográfica, trabalho de campo e a confecção de um mapa do roteiro, contendo os pontos de interesse geoturísticos. Por meio da pesquisa, foram levantadas as principais características físico-naturais do município de estudo, entre elas: Geologia, Geomorfologia, Hidrografia, entre outras, as quais fornecem a base para a elaboração do roteiro. No mês de junho de 2017, realizou-se um trabalho de campo para o levantamento de elementos da Geodiversidade, com o auxílio de máquina fotográfica, GPS, carta topográfica na escala 1:50.000 e caderno de campo. Das fotos tiradas em campo foram selecionadas nove que apresentam feições interessantes para a elaboração do roteiro. A confecção do mapa contendo o roteiro foi realizada com o auxílio do software Corel Draw ${ }^{\circledR}$ e do Google Earth ${ }^{\circledR}$. Com esta pesquisa, concluiu-se que o roteiro é um instrumento fundamental para a divulgação, valoração e conservação da Geodiversidade local, podendo colaborar também com a implantação do Geoturismo no município.
\end{abstract}

Palavras-Chaves: Georoteiro; Geodiversidade; Norte Paranaense.

\begin{abstract}
This research aims to raise and characterize some elements of Geodiversity for the elaboration of a Geoturistic Trail in the Brazilian city of Santo Antônio da Platina, along the PR - 439, PR - 092 and BR - 153 highways, located in the State of Paraná. Three procedural steps were involved in this research: the bibliographical research, a specific fieldwork and the preparation of a map containing the points of the Geoturistic Trail suggested. Through this research, the main physical and natural characteristics of the local studied were raised, including: Geology, Geomorphology, Hydrography, among others, which provide the basis for the Geoturistic Trail. In June 2017, a fieldwork for the survey of elements of Geodiversity was done, with a camera, GPS, topographic letter 1:50.000 scale and a field notebook. The pictures taken in the field, nine have been selected which present interesting features for the Geoturistic Trail. The making of the map containing Geoturistic Trail was performed with the aid of the software Corel Draw ${ }^{\circledR}$ and Google Earth ${ }^{\circledR}$. With this research, it was concluded that the Geoturistic Trail is a fundamental instrument for the dissemination, evaluation and conservation of the local Geodiversity and can collaborate also with the deployment of Geotourism in the local city.
\end{abstract}

Keywords: Geotrail; Geodiversity; North of Paraná.

\footnotetext{
${ }^{1}$ Esta pesquisa teve o apoio financeiro da Fundação Araucária e do CNPq.

${ }^{2}$ Mestre em Geografia da Universidade Estadual de Londrina. Professor da Rede Particular de Ensino de Marília

- SP, E-mail: euzemar.geografia@gmail.com

${ }^{3}$ Professor Adjunto D na Universidade Estadual de Londrina. E-mail: gilnei@uel.br
} 


\section{Introdução}

Roteiros geoturísticos podem ser instrumentos eficazes para a divulgação da Geodiversidade em uma área ou região. Assim, no contexto de atividade de lazer, estes podem apresentar ao público diferentes elementos físico-naturais, auxiliado a Geoconservação (AUGUSTO; DEL LAMA, 2010).

Segundo Mucivuna et al. (2016), roteiros geoturísticos ou georoteiros são itinerários que englobam um conjunto de locais de interesse geológico-geomorfológico e turístico. Estes podem envolver tanto o patrimônio natural como o cultural, sendo que ambos apresentam potencial de divulgação e popularização das Geociências.

Além destes roteiros promoverem a divulgação, conservação e valoração da Geodiversidade, também podem contribuir com a implantação de diversas atividades, dentre elas o Geoturismo (GUIMARÃES et al, 2013).

Conforme Guimarães et al. (2013), o Paraná é um dos estados brasileiros que mais implantaram roteiros geoturísticos, particularmente, na Serra do Mar, região metropolitana de Curitiba e Campos Gerais.

Devido ao fato do Norte Pioneiro se localizar em uma região de transição entre o Segundo e o Terceiro Planaltos Paranaenses, apresenta diversos elementos da Geodiversidade. Santo Antônio da Platina é um dos municípios que estão inseridos nesta mesorregião, apresentando elementos geológico-geomorfológicos, pedológicos e biológicos diversos.

Desta forma, o objetivo desta pesquisa é o levantamento e a caracterização de elementos da Geodiversidade do município de estudo, ao longo das PR - 439, PR - 092 e BR 153, para a elaboração de um roteiro geoturístico, visando contribuir com a divulgação e promoção da Geodiversidade local e também com a sua conservação e valoração, podendo colaborar com a implantação do Geoturismo. 


\section{Desenvolvimento}

A Geodiversidade em Santo Antônio da Platina

Embora os elementos não vivos, também denominados de Geodiversidade ${ }^{4}$, sejam à base de fixação e desenvolvimento dos seres vivos e um dos testemunhos da evolução do planeta Terra, percebe-se que este substrato tem recebido pouca importância quando comparado a Biodiversidade ${ }^{5}$ (VIEIRO et al., 2010).

Assim, na década de 1990, uma parcela da comunidade científica preocupada com a degradação da Geodiversidade, passou a desenvolver pesquisas envolvendo a proteção dos elementos não vivos, principalmente no continente australiano e europeu.

No Brasil, as pesquisas que abrangem a proteção da Geodiversidade surgiram no final da década de 1990, no entanto, se intensificaram nos anos 2000. Sendo influenciadas por estudos e projetos que envolveram a Geoconservação, como por exemplo, a criação do geoparque Araripe no Ceará em 2006.

Pelo fato do território brasileiro possuir dimensões continentais, com a presença de uma ampla variedade de elementos geológico-geomorfológicas e biológicas, este é dotado de diversos elementos da Geodiversidade, os quais, na maioria das vezes, não tem sido devidamente conservados, o que tem contribuído para a degradação de elementos naturais que se destacam pelo seu valor científico e paisagístico.

O Paraná é um estado brasileiro que apresenta importantes elementos da Geodiversidade, como pode-se verificar nas palavras de Guimarães et al. (2013, p. 42):

[...] pode-se afirmar com segurança que o Paraná é um estado com uma expressiva geodiversidade [...]. Do Paleoproterozoico (eventualmente desde o Arqueano) ao Holoceno encontra-se um amplo espectro de produtos magmáticos, sedimentares e metamórficos, em diferentes ambientes geotectônicos, controlando uma variada gama de tipos de solos, formas de relevo e mineralizações [...].

O estado do Paraná possui formações vegetais de destaque, dentre elas: a Floresta de Araucária (Floresta Ombrófila Mista), cujos principais remanescentes estão localizados na região centro-sul do estado; os Campos ou Estepes, com especial destaque para os Campos

\footnotetext{
${ }^{4}$ Neste caso, a Geodiversidade compreende apenas os elementos não vivos. No entanto, para Nascimento et al. (2008), ela também abrange os processos responsáveis pela sua gênese e transformação. Brilha (2005), por sua vez, destaca que a Geodiversidade pode envolver as comunidades de seres vivos (Biodiversidade).

${ }^{5}$ A Biodiversidade aqui, compreende apenas os seres vivos, tais como: vegetais, animais, entre outros.
} 
Gerais localizados no Segundo Planalto Paranaense; a Floresta Atlântica (Floresta Ombrófila Densa) na Serra do Mar; a Floresta Atlântica de Interior (Floresta Latifoliada Semidecidual), notadamente no norte do estado; entre outras.

O município de Santo Antônio da Platina (Figura 1), é um município paranaense localizado na mesorregião Norte Pioneiro. A respeito de sua Geodiversidade, percebe-se que abrange uma ampla variedade de elementos físico-naturais, em especial aqueles dotados de excepcional valor científico, educacional e estético, com a presença de afloramentos rochosos de origem magmática e sedimentar, relevos assimétricos, diferentes tipos de solos, anomalias de drenagem, remanescentes florestais, entre outros.

Figura 1 - Mapa de localização do município de Santo Antônio da Platina (PR).

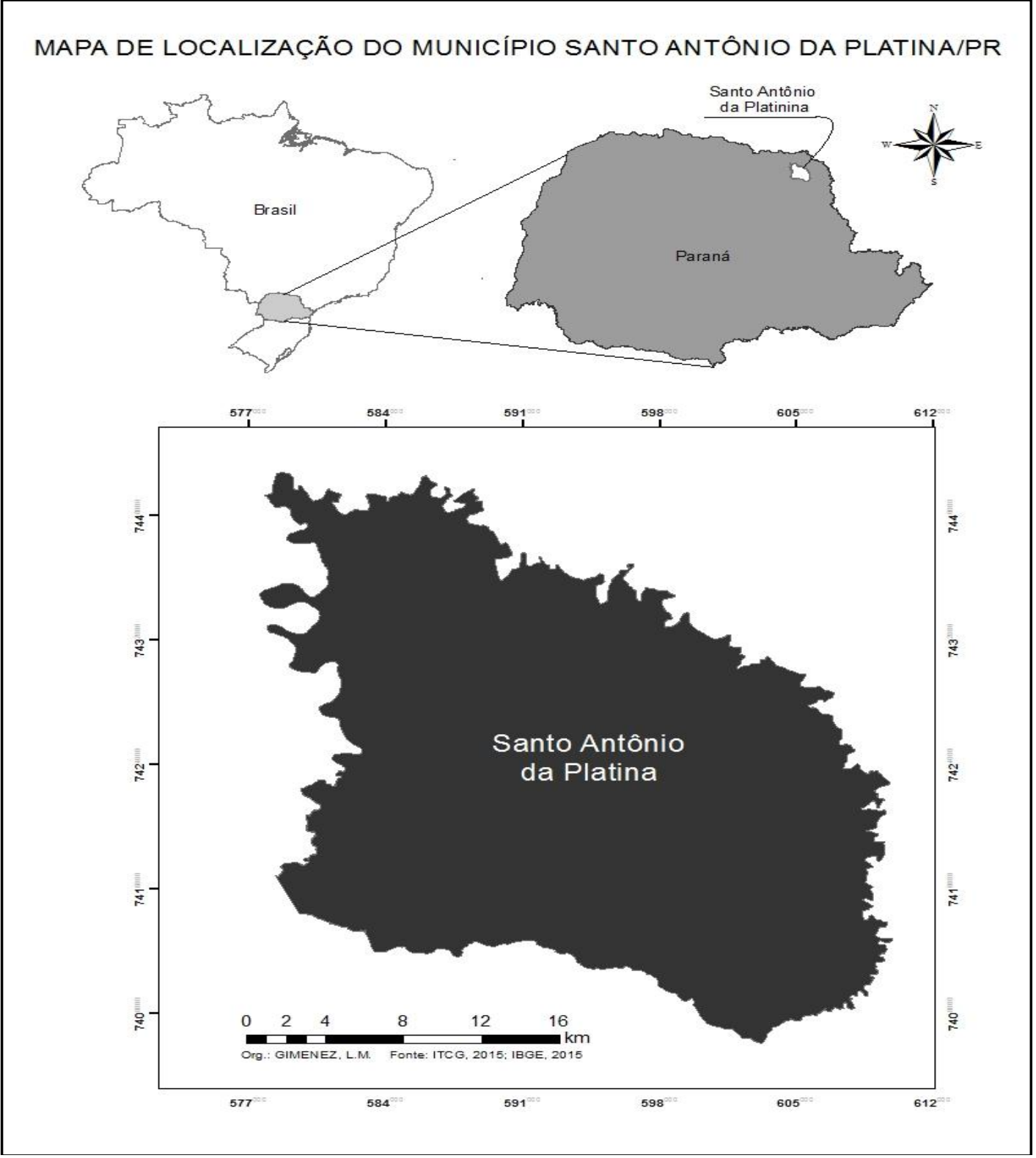

Fonte: Florentino Junior e Machado (2017, p. 9911). 
Do ponto de vista geológico, o município de estudo está inserido na Bacia Sedimentar do Paraná ${ }^{6}$ Em seu território afloram rochas sedimentares das Formações Teresina e Rio do Rasto, pertencentes ao Grupo Passa Dois; e também, rochas sedimentares das Formações Pirambóia e Botucatu, e ígneas da Formação Serra Geral, pertencentes ao Grupo São Bento.

A variação entre rochas ígneas com alta resistência à denudação e sedimentares com baixa resistência aos processos intempéricos e erosivos em Santo Antônio da Platina, influenciou a formação de um relevo escarpado, com a presença de morros testemunhos e platôs, contribuindo para a formação de uma paisagem agradável do ponto de vista cênico (MINEROPAR, 2006).

Os solos deste município variam consideravelmente conforme a área de localização. Assim, há solos arenosos originados das rochas sedimentares e argilosos, provenientes das rochas magmáticas, dentre eles destacam-se: Nitossolos, Latossolos, Neossolos Litólicos, Argissolos, entre outros.

A principal bacia hidrográfica que percorre Santo Antônio da Platina é a bacia do Rio das Cinzas, a qual apresenta anomalias de drenagem formadas principalmente pela influência tectônica e mudanças climáticas ocorridas no quaternário (SANTOS et al. 2016). Tais anomalias se destacam na paisagem local.

O município de estudo também apresenta importantes remanescentes florestais, em especial da Floresta Latifoliada Semidecidual. Esta constitui-se em uma vegetação que pertence ao bioma Mata Atlântica (Mata Atlântica de Interior), típica do Brasil Central, sendo condicionada pela dupla estacionalidade climática: verão chuvoso e inverno seco. Desta forma, no período mais seco a vegetação perde parcialmente suas folhas (KLIMANATURALI, 2018).

Destaca-se que a Geodiversidade de Santo Antônio da Platina têm sido degradada pela ação humana, principalmente por causa da exploração de rochas para fins comerciais, entre elas: os arenitos da Formação Botucatu e os argilitos da Formação Rio do Rasto.

Assim, para que haja a conservação e a valoração dos elementos da Geodiversidade no município de estudo torna-se necessária a difusão do conhecimento de sua importância para a população "leiga", devendo este ser realizado por meio de práticas que contemplem a

\footnotetext{
${ }^{6}$ Segundo Milani et al. (2007), a Bacia Sedimentar do Paraná é uma ampla região sedimentar que abrange partes do Brasil, Paraguai, Argentina e Uruguai. Esta tem forma ovalada com eixo maior N-S, sendo que seus contornos atuais são definidos por limites erosivos relacionados à história geotectônica meso-cenozóica do continente sul americano.
} 
educação ambiental, tais como: trabalhos de campo, palestras, entre outras atividades (NASCIMENTO et al., 2008).

Para Troppmair (2008) a educação ambiental tem por objetivo a preservação e/ou conservação das condições ambientais, abrangendo tanto os elementos vivos como os não vivos, garantindo a continuação e perpetuação das espécies vivas do planeta Terra, inclusive o ser humano. Andretta et al. (2007), por sua vez, destacam que a aplicação de práticas voltadas a educação ambiental é essencial para despertar nos sujeitos novas atitudes, colaborando com a qualidade de vida dos seres vivos.

Desta maneira, para que a Geodiversidade em Santo Antônio da Platina seja protegida, há a necessidade da implantação de um sistema de gestão que contribua com a divulgação, valoração e conservação da mesma, devendo ser composto por pesquisadores e por representantes da administração pública e população local.

Potencial Geoturístico em Santo Antônio da Platina

O levantamento dos elementos naturais de uma determinada área ou região é o principal fator para a avaliação de seu potencial turístico (ANDRADE, 1995). Pelo fato de Santo Antônio da Platina apresentar diversos elementos da Geodiversidade, notadamente aqueles que se destacam pelo seu valor científico e paisagístico, percebe-se que possui elevado potencial geoturístico.

No entanto, a avaliação deste potencial não depende apenas do levantamento da Geodiversidade local, mas também, da infraestrutura turística e dos meios de comunicação do município.

O termo infraestrutura turística se refere ao conjunto de instalações e de estruturas físicas e de serviços urbanos que são a base para o desenvolvimento turístico de uma região, como por exemplo: hotéis, postos de informações, sistemas de transportes e comunicações, entre outros. Destaca-se que a instalação destas benfeitorias depende de estudos e investimentos, tanto do setor público como privado (MINISTÉRIO DO TURISMO, 2017).

Em relação a infraestrutura turística em Santo Antônio da Platina, verifica-se que este município possui um número considerável de hotéis, pousadas, restaurantes, estradas, e pontos de observação. No entanto, para que haja a implantação do Geoturismo, há a necessidade de ampliação e melhoria da infraestrutura local, uma vez que haverá o aumento do fluxo de turistas. 
A implantação do Geoturismo também depende da divulgação das belezas naturais e cênicas, bem como da infraestrutura turística das localidades envolvidas. Esta deve ser realizada por meio de diferentes meios de comunicação, tais como: websites, outdoors, emissoras de rádio e TV.

O site da prefeitura de Santo Antônio da Platina possui uma área que apresenta fotos de pontos turísticos do município (Figura 2), porém, destacam pouco a Geodiversidade local. Desta forma, a eficácia do Geoturismo exige ampla divulgação dos elementos físico-naturais. Tal divulgação deve ser realizada por meio de diferentes meios de comunicação, entre eles: sites, emissoras de rádio e outdoors.

Finalmente, a implantação do Geoturismo também depende do levantamento das características econômicas, sociais e culturais das localidades envolvidas, o que deve ser realizado com o auxílio de pesquisadores de diversas áreas do conhecimento, como geógrafos, economistas e sociólogos. Com isso, percebe-se que o levantamento destas características em Santo Antônio da Platina é fundamental para a implantação do Geoturismo no município, havendo a necessidade da elaboração de pesquisas que auxiliem o mesmo.

Figura 2 - Morro Testemunho localizado na área urbana de Santo Antônio da Platina.

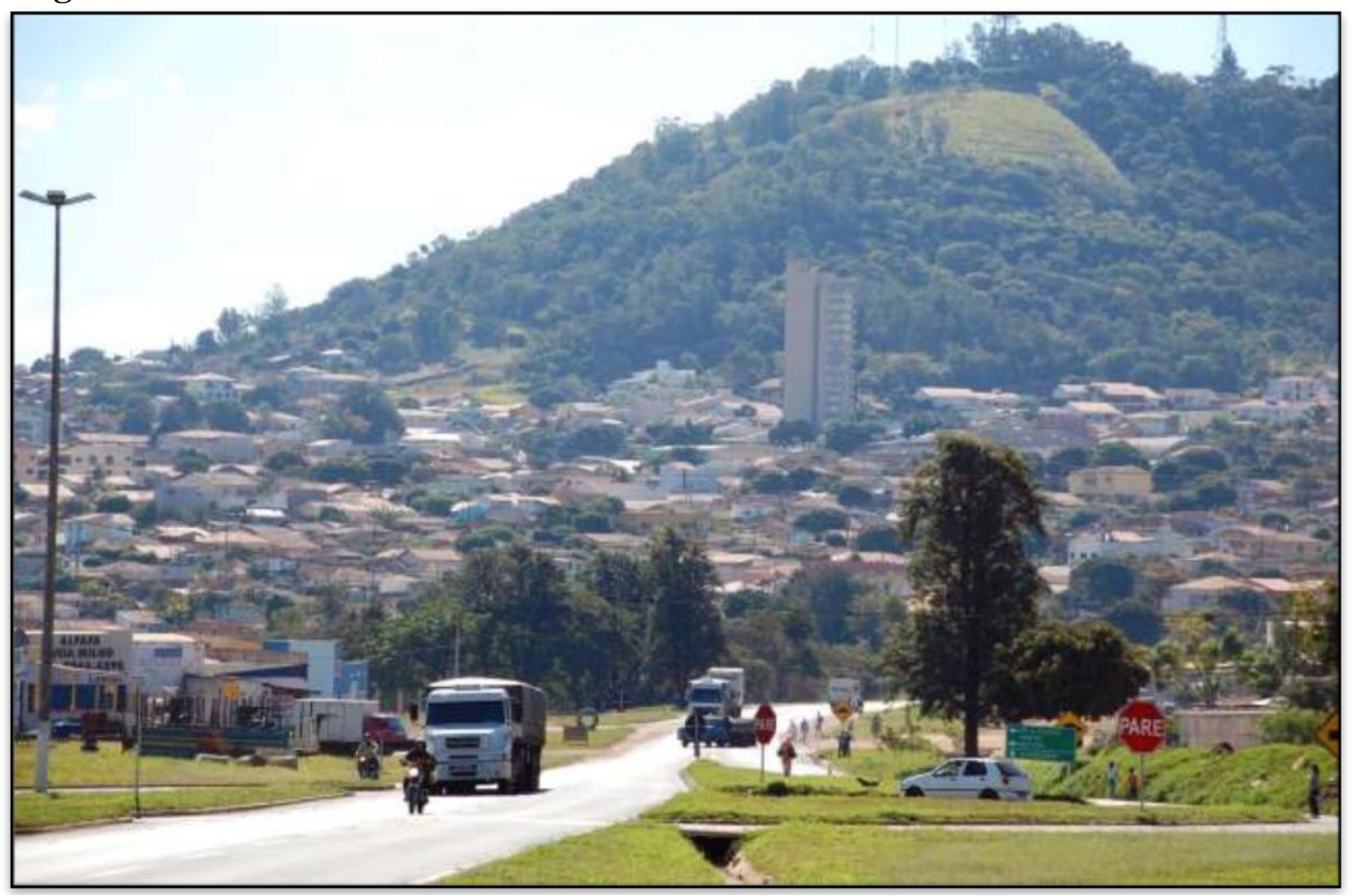

Fonte: Prefeitura Municipal de Santo Antônio da Platina (2018). 
Proposta de um roteiro geoturístico em Santo Antônio da Platina

Há décadas a comunidade geocientífica tem utilizado os roteiros geoturísticos como instrumentos para a divulgação e promoção da Geodiversidade. Neste sentido, o estado do Paraná apresenta importantes exemplos de sua aplicação (GUIMARÃES et al., 2013).

Segundo Florentino Junior (2014), roteiros geoturísticos ou georoteiros podem ser interpretados como roteiros de natureza geológica, geomorfológica, de beleza cênica, arquitetônica, dentre outros, criados ao longo de estradas e trilhas, por meio da demarcação geográfica de pontos selecionados que apresentem feições de interesse conforme sua finalidade, tendo como características comuns a divulgação, valoração e conservação do patrimônio natural e/ou cultural de uma determinada área ou região.

Guimarães et al. (2013), por sua vez, afirmam que estes roteiros auxiliam a difusão de conhecimentos sobre a Geodiversidade, sendo utilizados tanto no campo do Geoturismo como da educação, seja formal ou não-formal.

A elaboração de um roteiro geoturístico em Santo Antônio da Platina é fundamental para a proteção da Geodiversidade local. Nesta pesquisa este procedimento envolveu três etapas: pesquisa bibliográfica, trabalho de campo e a confecção de um mapa do roteiro com os pontos de interesse geoturístico.

Por meio da pesquisa bibliográfica, levantou-se materiais acerca das principais características físico-naturais de Santo Antônio da Platina, dentre elas: Geologia, Geomorfologia, Hidrografia, entre outras.

No dia 7 de junho de 2017, foi realizado um trabalho de campo ao longo das PR 439, PR - 092 e BR - 153, no município em estudo, por meio com o objetivo de levantar e caracterizar os elementos da Geodiversidade local. Para tanto, utilizou-se máquina fotográfica, GPS, carta topográfica na escala de 1:50.000 e caderno de campo.

Das mais de 100 fotos de elementos da Geodiversidade potencialmente interessantes para a elaboração de um roteiro geoturístico, foram selecionadas 9 fotos. Após esta seleção foi confeccionado um mapa do roteiro contendo os pontos de interesse (Figura 3), por meio do software Corel Draw ${ }^{\circledR}$ tendo como base a imagem de alta resolução disponibilizada pelo Google Earth®. 
Figura 3 - Roteiro Geoturístico do município de Santo Antônio da Platina - PR.

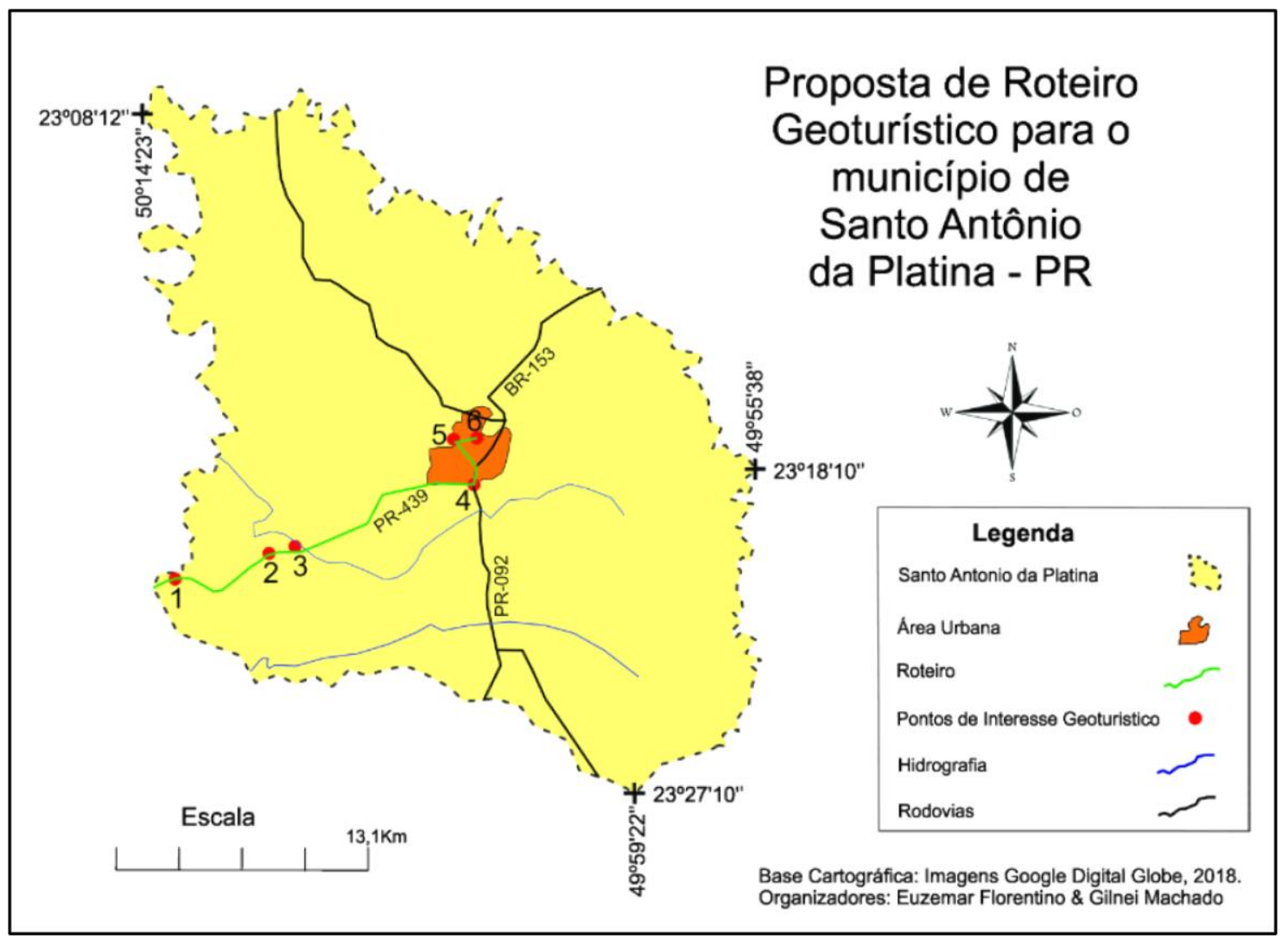

Fonte: Euzemar Florentino Junior e Gilnei Machado (2018).

\section{Ponto 1: Cabeceira de drenagem em anfiteatro e morro testemunho}

O ponto $\mathrm{n}^{\circ} 1$, situa-se nas coordenadas $23^{\circ} 21^{\prime} 8.73^{\prime \prime} \mathrm{S}$ de latitude e $50^{\circ} 13^{\prime} 19.44^{\prime \prime O}$ de longitude, ao longo da PR-439, próximo ao limite dos municípios de Santo Antônio da Platina e Abatiá (PR).

Neste local, na margem esquerda da rodovia, de Abatiá em direção à Santo Antônio da Platina, encontra-se uma cabeceira de drenagem em formato de anfiteatro e um morro testemunho (Figura 4).

As cabeceiras de drenagem ${ }^{7}$ podem ter sua origem ligada ao processo de erosão diferencial $^{8}$, em função da presença de litologias com resistências diferenciadas, como é o caso da área que apresentam arenitos recobertos com basaltos e as diferentes camadas dos arenitos da Formação Botucatu também apresentam resistências diferenciadas.

\footnotetext{
${ }^{7}$ Segundo Guerra e Guerra (2001), cabeceiras de drenagem em anfiteatro se referem as bacias, ou vales não canalizados, denominados de bacias de ordem zero. Geralmente, estas são caracterizadas por uma conformação topográfica côncava em planta, correspondendo aos primeiros formadores da rede de drenagem, podendo constituir o prolongamento da nascente dos canais fluviais de $1^{\mathrm{a}}$ ordem.

${ }^{8}$ Erosão diferencial é aquela que ocorre por meio do trabalho desigual dos agentes erosivos ao devastarem a superfície do relevo (GUERRA; GUERRA, 2001).
} 
Machado e Moura (1982) fazem a conexão entre o formato dos anfiteatros com a presença das rampas de colúvio ${ }^{9}$ ou mesmo de depósitos coluviais ${ }^{10}$, materiais movimentados e depositados na encosta próxima à área de nascente.

Figura 4 - Ponto 1: Cabeceira de drenagem em anfiteatro e morro testemunho.

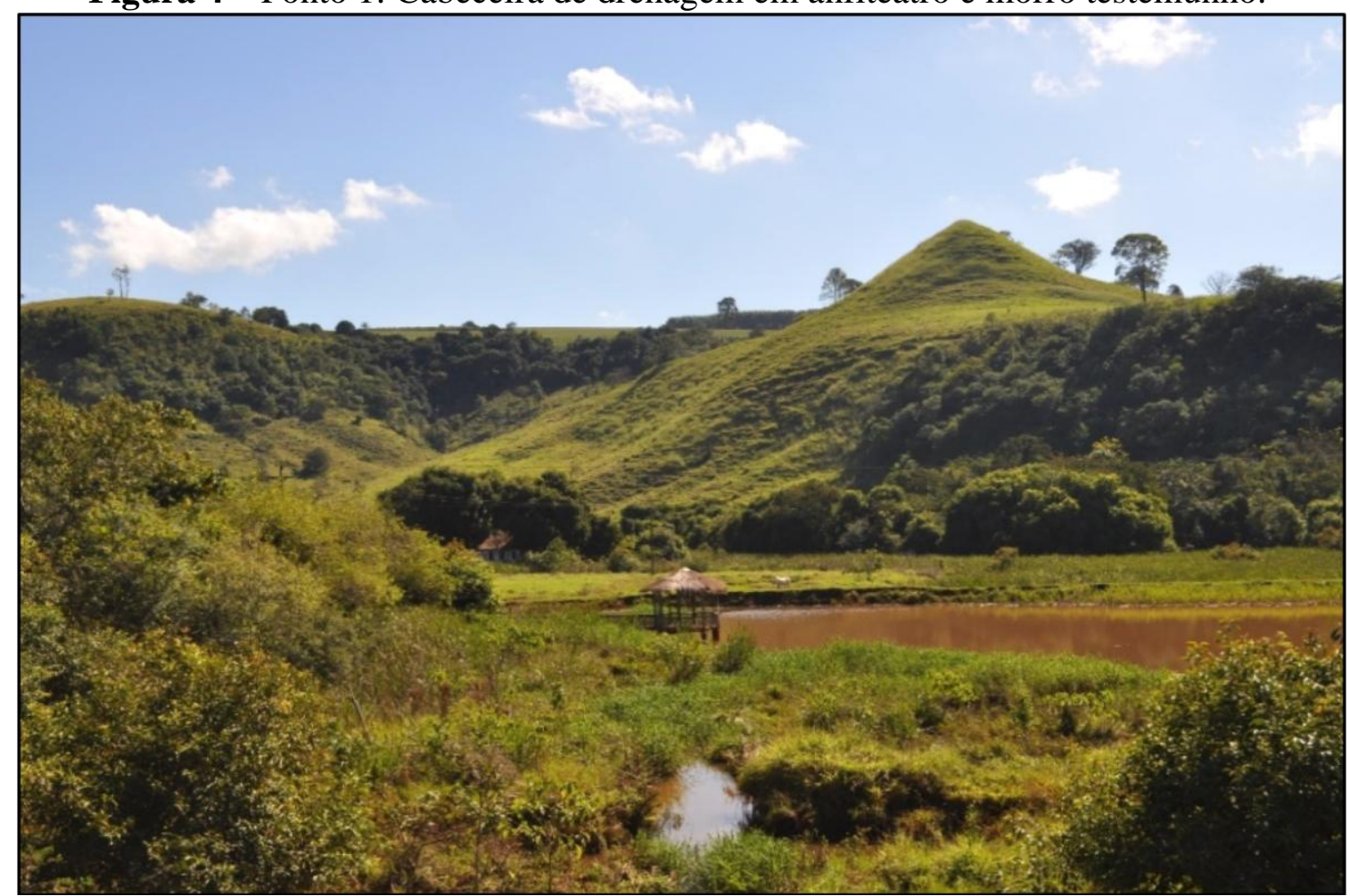

Fonte: Euzemar Florentino Junior (2018).

Felizola e Boulet (1996) destacam que a denudação química ${ }^{11}$ é um elemento fundamental na formação e evolução dos anfiteatros de cabeceiras de drenagem. Os morros testemunhos, por sua vez, são morros residuais presentes nas áreas de bacias sedimentares que, como o próprio nome diz, testemunham a forma que o relevo apresentava antes de ser erodido.

O Morro testemunho, normalmente, se apresenta como uma colina de topo plano situada diante da escarpa de uma cuesta ${ }^{12}$, mantida pela camada resistente. Ele é um

\footnotetext{
${ }^{9}$ Para Suguio (1998, p. 650), rampa de colúvio é uma "Superfície de sedimentação situada na parte inferior de um terreno declivoso, cujos depósitos resultam de transporte do material intemperizado por rastejo (creep) $[\ldots] "$.

${ }^{10}$ Depósitos coluviais são incoerentes, de aspecto terroso, situados em vertentes e em sopés de relevo mais ou menos acentuados (SUGUIO, 1998).

${ }^{11}$ Conforme Guerra e Guerra (2001), o termo denudação se refere ao arrasamento do relevo mais saliente por meio de processos que envolvem diferentes agentes erosivos. No caso da denudação química, há o predomínio de processos químicos.

${ }^{12}$ Guerra e Guerra (2001, p. 178) afirmam que uma cuesta é uma "Forma de relevo dissimétrico constituída pela sucessão alternada das camadas com diferentes resistências ao desgaste e que se inclinam numa direção, formando um declive suave no reverso, e um corte abrupto ou íngreme na chamada frente de cuesta [...]”.
} 
EM

QUESTÃO

pág. 9-30

fragmento do reverso, sendo um testemunho da antiga posição da cuesta antes do recuo do front.

Ponto 2: Arenito da Formação Botucatu metamorfizado pelo contato com os basaltos da Formação Serra Geral

O ponto $\mathrm{n}^{\mathrm{o}} 2$, também se localiza ao longo da rodovia PR-439, nas coordenadas $23^{\circ} 20^{\prime} 19.70^{\prime \prime S}$ de latitude e $50^{\circ} 10^{\prime} 22.06^{\prime \prime} \mathrm{O}$ de longitude, próximo ao limite dos municípios de Santo Antônio da Platina e Abatiá.

Neste ponto, observa-se um conjunto de rochas da Formação Serra Geral altamente intemperizadas expostas em um corte na rodovia PR-439, onde o intemperismo físico ${ }^{13} \mathrm{e}$ químico ${ }^{14}$ tem atuado para a formação de fragmentos finos e mais grosseiros com coloração avermelhada devido à presença de ferro na rocha (Figura 5).

Figura 5 - Ponto 2: Afloramento de basalto intemperizado com alto teor de ferro -Margens da rodovia $\mathrm{PR}-439$.

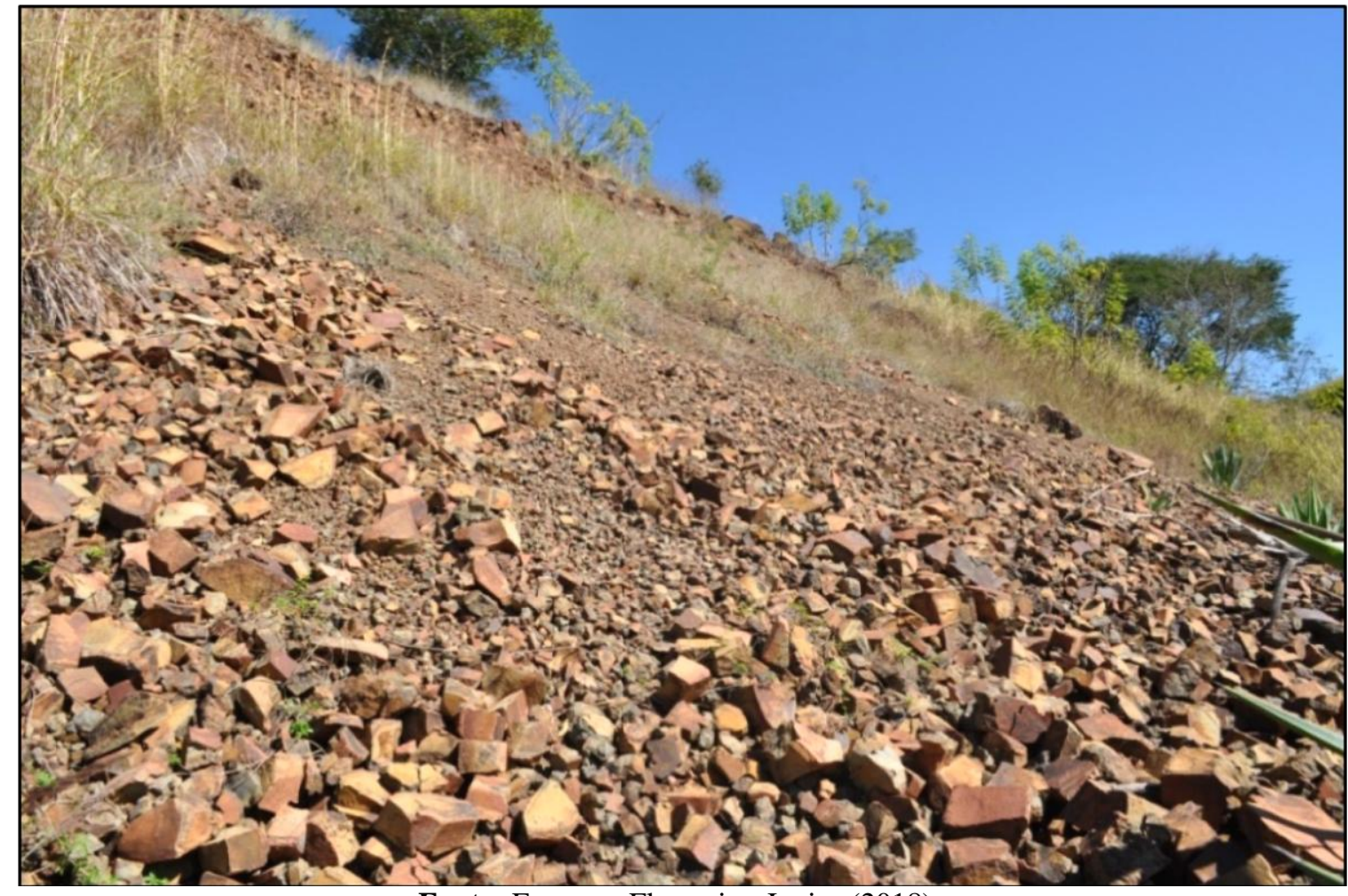

Fonte: Euzemar Florentino Junior (2018).

\footnotetext{
${ }^{13}$ Suguio (1998) entende que o intemperismo físico é um fenômeno pelo qual uma rocha é destruída sem passar por qualquer tipo de alteração química. Dentre os processos responsáveis por este tipo de intemperismo, podese citar: dilatação e contração térmicas, congelamento de água nas fraturas das rochas, entre outros.

${ }^{14} \mathrm{O}$ intemperismo químico ocorre quando as rochas da crosta terrestre passam por mudanças químicas ocasionadas pelo contato com a atmosfera, biosfera e/ou hidrosfera. Este tipo de intemperismo progride por meio de diversos processos, tais como: oxidação, dissolução, carbonatação, dentre outros (SUGUIO, 1998).
} 
Assim, o processo de intemperismo físico promoveu a fragmentação da rocha em pequenos blocos, o que a torna muito economicamente viável para o embelezamento de fachadas de casas e áreas de piscina.

Ponto 3: Afloramento de basalto da Formação Serra Geral, anomalia de drenagem no Rio das Cinzas e depósitos fluviais ao longo das margens do Rio das Cinzas

$\mathrm{O}$ ponto $\mathrm{n}^{\circ} 3$, situa-se nas coordenadas $23^{\circ} 20^{\prime} 18.01$ "S de latitude e $50^{\circ} 10^{\prime} 23.59^{\prime \prime} \mathrm{O}$ de longitude. Neste local é possível observar vários elementos da Geodiversidade, por isso optou-se pela apresentação de três imagens fotos, a saber: pontos especificados nas Figuras 6, $7 / 8$ e 9 , respectivamente.

$\mathrm{Na}$ Figura 6 é possível visualizar uma formação geológico-geomorfológica denominada popularmente de "mirante", localizada as margens da rodovia PR-439, próximo ao Rio das Cinzas. Esta pode ser caracterizada como um grande corpo de rocha basáltica da Formação Serra Geral, o qual se apresenta com alto teor de ferro, o que explica a coloração avermelhada e não a tradicional cinza escura ou preta dos basaltos.

Figura 6 - Afloramento de basalto com alto teor de ferro - Margens PR-439.

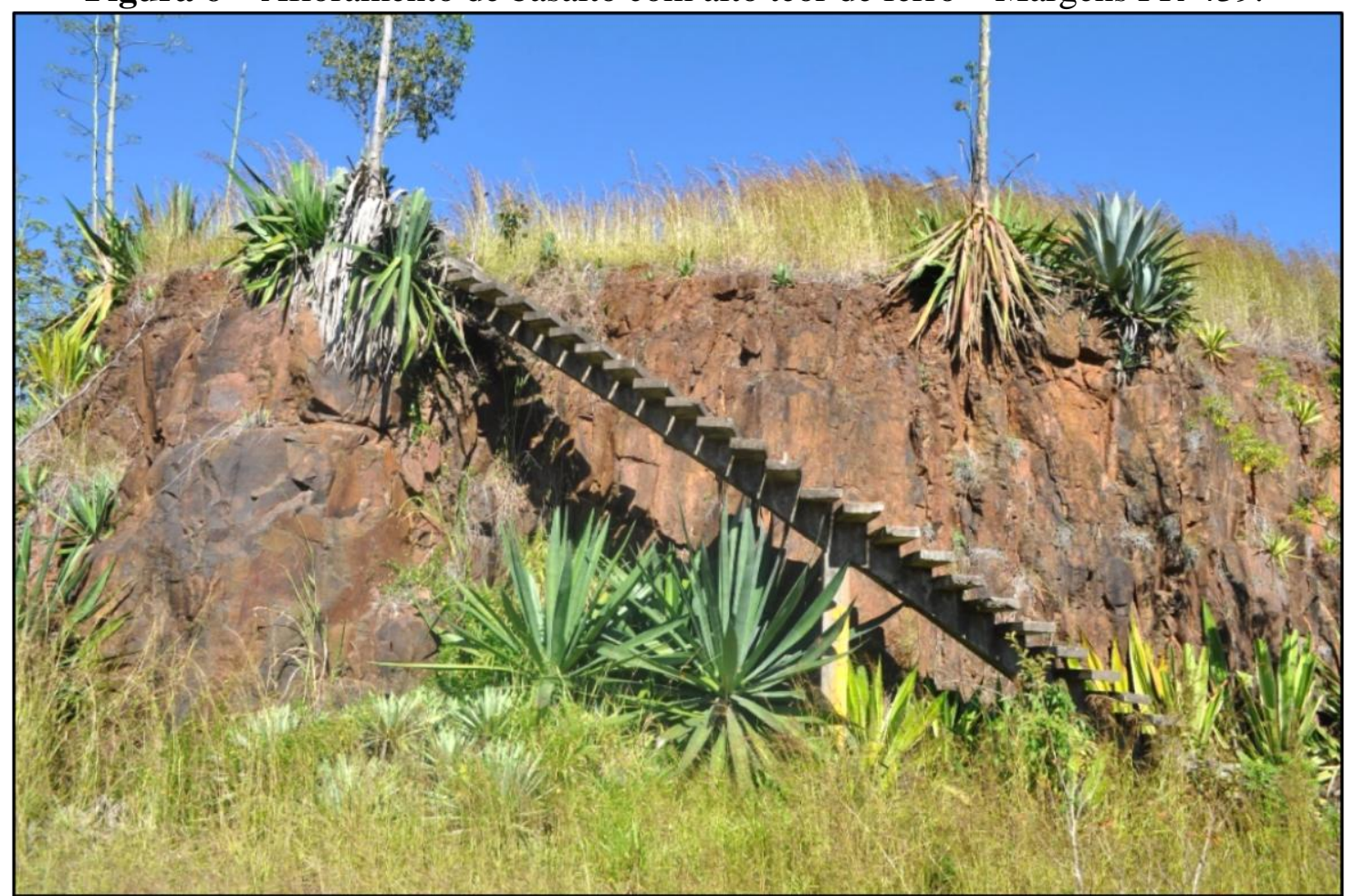

Fonte: Euzemar Florentino Junior (2018). 
Nesta formação destaca-se uma série de fraturamentos ${ }^{15}$ e falhamentos ${ }^{16}$ (de pequenas dimensões), bem como a presença de diques ${ }^{17}$, apresentando-se como um ótimo laboratório de Geologia a céu aberto.

As Figuras 7 e 8 demonstram um trecho do Rio das Cinzas, próximo à Rodovia PR439. Por meio delas, especialmente da Figura 8, é possível observar anomalias de drenagem existentes na bacia deste rio. Tais anomalias foram originadas a partir do controle estrutural existente na região, normalmente relacionadas às falhas na estrutura rochosa, que dá um direcionamento abrupto ao rio, diferente daquele que ele tinha poucos metros antes. Isso pode ocorrer também em função da presença de corpos rochosos resistentes, porém, no caso da área de estudo, o controle estrutural ocorre basicamente em função das falhas aí presentes.

Também é possível visualizar na área o conjunto de cuestas que são encontradas margeando o Rio das Cinzas e que demarcam, em partes, o limite do Segundo Planalto Paranaense com o Terceiro. A Figura 8 mostra o trecho fotografado.

Figura 7 - Anomalia de rede de drenagem no Rio das Cinzas.

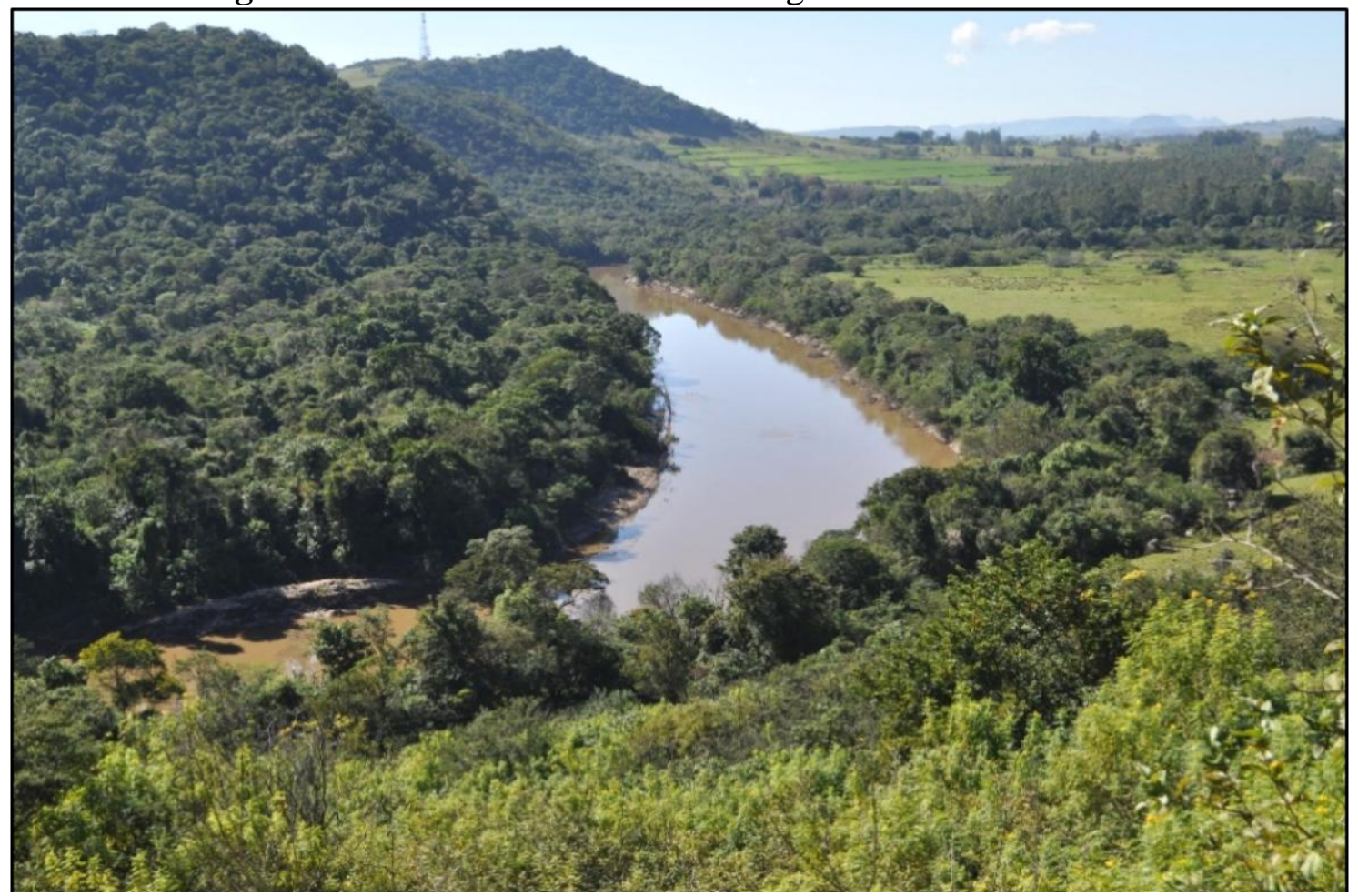

Fonte: Euzemar Florentino Junior (2018).

\footnotetext{
${ }^{15}$ Fraturamento é um processo de rompimento parcial de um corpo em resposta a uma força aplicada. O aspecto da fratura pode variar conforme: a temperatura do corpo, a velocidade de aplicação do esforço, entre outros fatores (SUGUIO, 1998).

16 "Ruptura e desnivelamento na continuidade das camadas que apresentaram certo grau de rigidez por ocasião dos movimentos tectônicos. Estes esforços dão o aparecimento de certas formas de relevo chamadas estruturas falhadas [...]" (GUERRA; GUERRA, 2001, p. 265).

${ }^{17}$ Para Guerra e Guerra (2001), diques ou filões são intromissões de magma em forma alongada através das camadas da crosta terrestre.
} 
Figura 8 - Trecho do Rio das Cinzas.

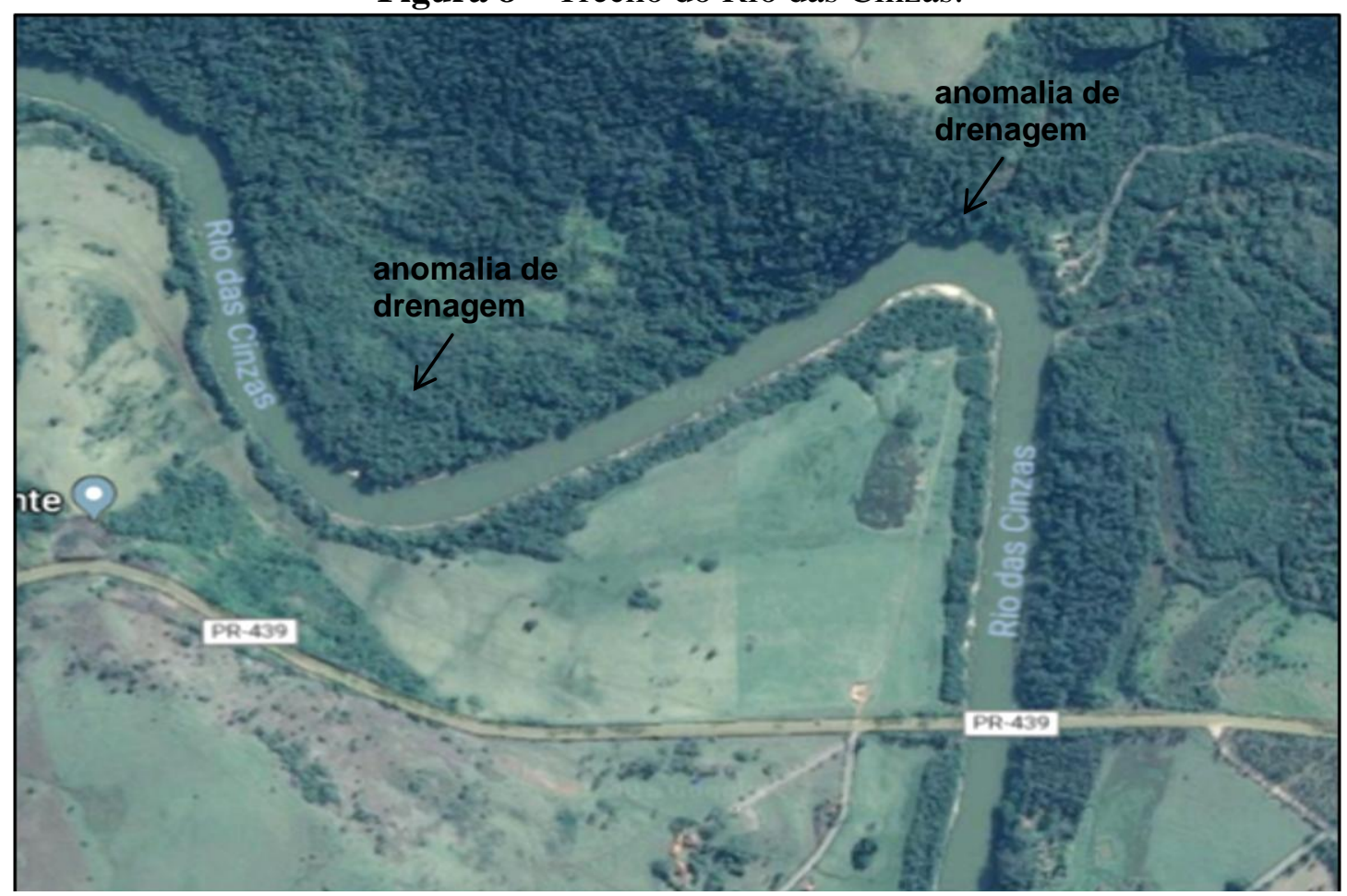

Fonte: Google Maps (2018).

A Figura 9, localiza-se nas cordenadas $23^{\circ} 20^{\prime} 26.91 " \mathrm{~S}$ de latitude e $50^{\circ} 9^{\prime} 46.57^{\prime \prime O}$ de longitude. Por meio desta é possível visualizar uma área recoberta por mata ciliar (mata galeria) e uma série de depósitos fluviais nas margens do Rio das Cinzas.

Figura 9 - Mata ciliar e depósitos fluviais de margem - Rio das Cinzas.

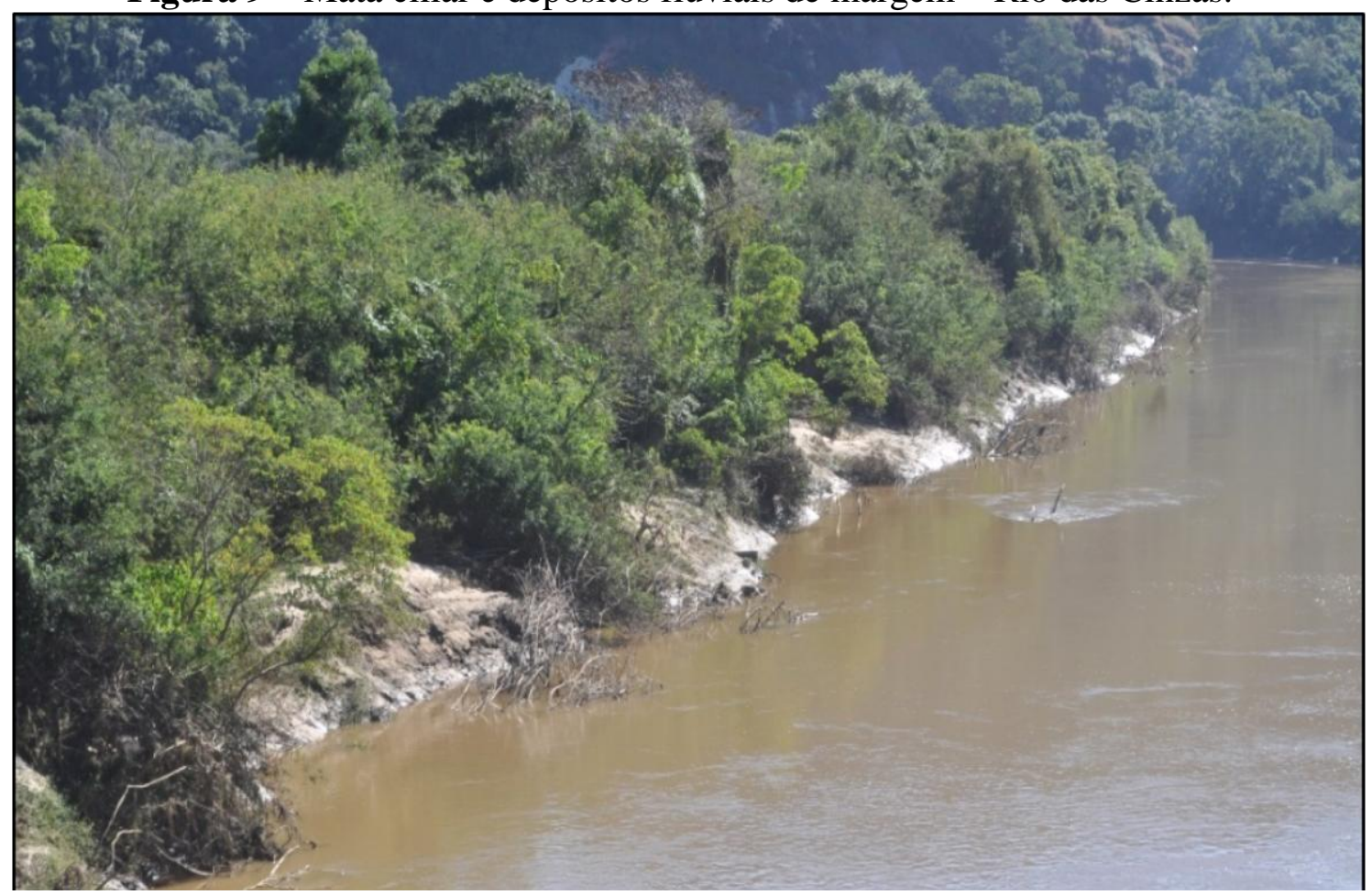

Fonte: Euzemar Florentino Junior (2018). 
Matas ciliares ou matas galeria são florestas ou outros tipos de vegetação nativa, que ficam às margens de rios, lagos, nascentes, entre outros. Esta vegetação recebe este nome pois é fundamental para a proteção dos corpos d'água, assim como os cílios são essenciais para a proteção dos olhos (WWF, 2018). Destaca-se que neste trecho, a mata ciliar do Rio das Cinzas encontra-se relativamente bem preservada.

Segundo Guerra e Guerra (2001), depósitos fluviais são materiais acumulados pelos rios ao longo dos períodos mais chuvosos. Como se pode observar na Figura 9, os depósitos fluviais do Rio das Cinzas neste trecho são formados por materiais bem diversificados, tais como: areias, matéria orgânica proveniente da vegetação e resíduos de natureza humana.

\section{Ponto 4: Afloramento da Formação Botucatu em corte de estrada e morro testemunho}

O ponto $\mathrm{n}^{\circ} 4$, situa-se nas coordenadas $23^{\circ} 16^{\prime} 56.09^{\prime \prime} \mathrm{S}$ de latitude e $50^{\circ} 3^{\prime} 44.68^{\prime \prime} \mathrm{O}$ de longitude. Pelo fato de ser possível observar dois importantes elementos da Geodiversidade através deste ponto, optou-se pela sua apresentação via duas imagens, Figuras 10 e 11.

A Figura 10 demonstra um afloramento de pacotes de rochas sedimentares com cores acinzentadas assemelhadas a folhelhos e siltitos em um corte na estrada, coerentes com as características da Formação Teresina encontradas na região e descritas por Fernandes e Coimbra (1993), originadas a partir de ambiente marinho raso com planícies de maré conforme destacado por Andreis e Carvalho (2001).

Figura 10 - Afloramento da Formação Botucatu em Corte de Estrada.

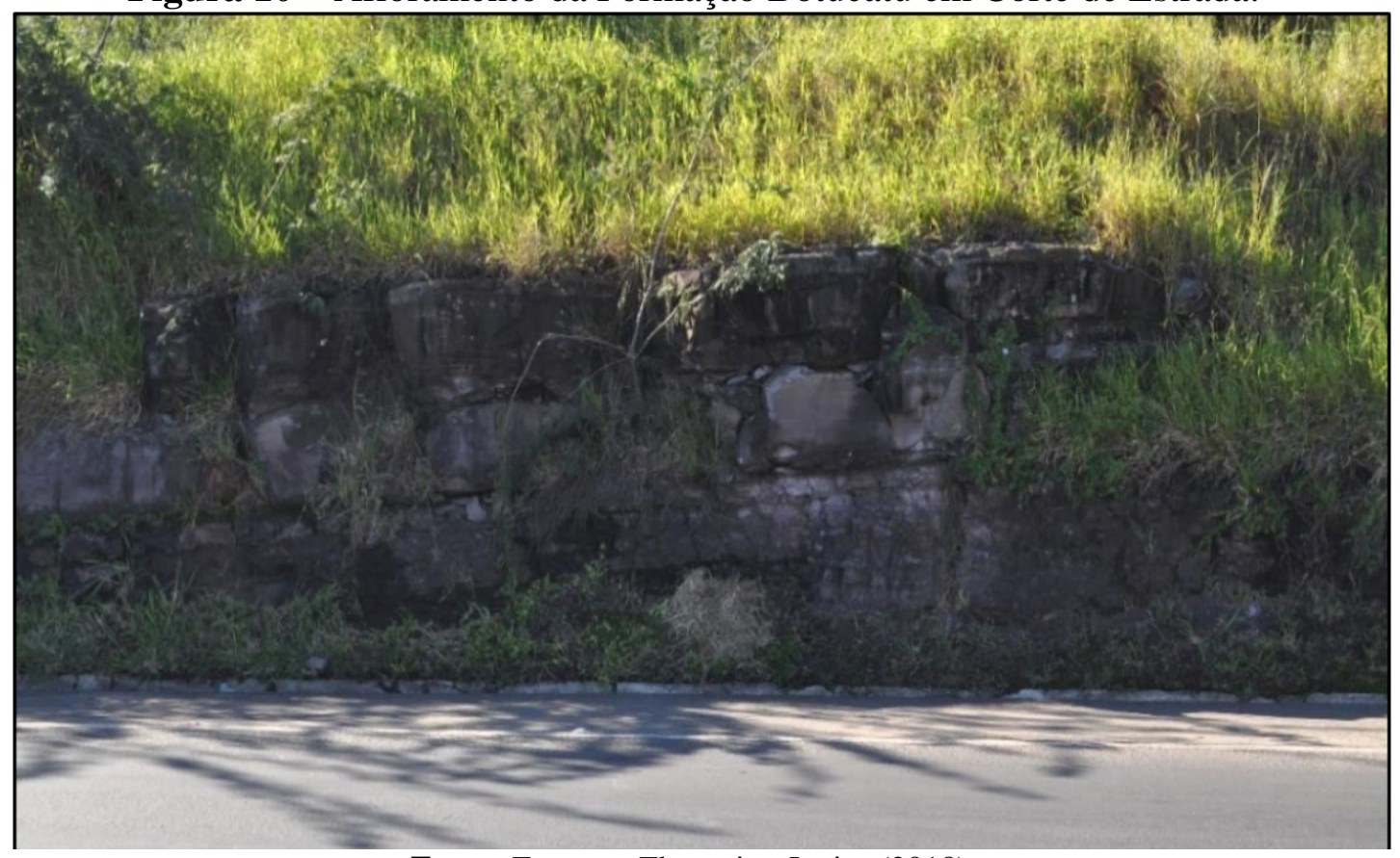

Fonte: Euzemar Florentino Junior (2018). 
O Membro Serrinha da região de Santo Antônio da Platina apresenta estas características. Ele é constituído por arenitos finos, bem selecionados, intercalados com siltitos e argilitos cinza-esverdeados, amarronzados, bordôs e avermelhados, podendo conter lentes ou horizontes de calcário margoso.

Por meio da análise da Figura 11 é possível observar um morro testemunho que demarca a antiga localização do relevo de cuestas. Este é denominado Morro das Antenas e faz parte do "complexo" Morro do Binda, o qual é um ponto turístico interessante por apresentar-se como um mirante de boa parte da área urbana do município de Santo Antônio da Platina e da paisagem próxima.

Figura 11 - Morro testemunho.

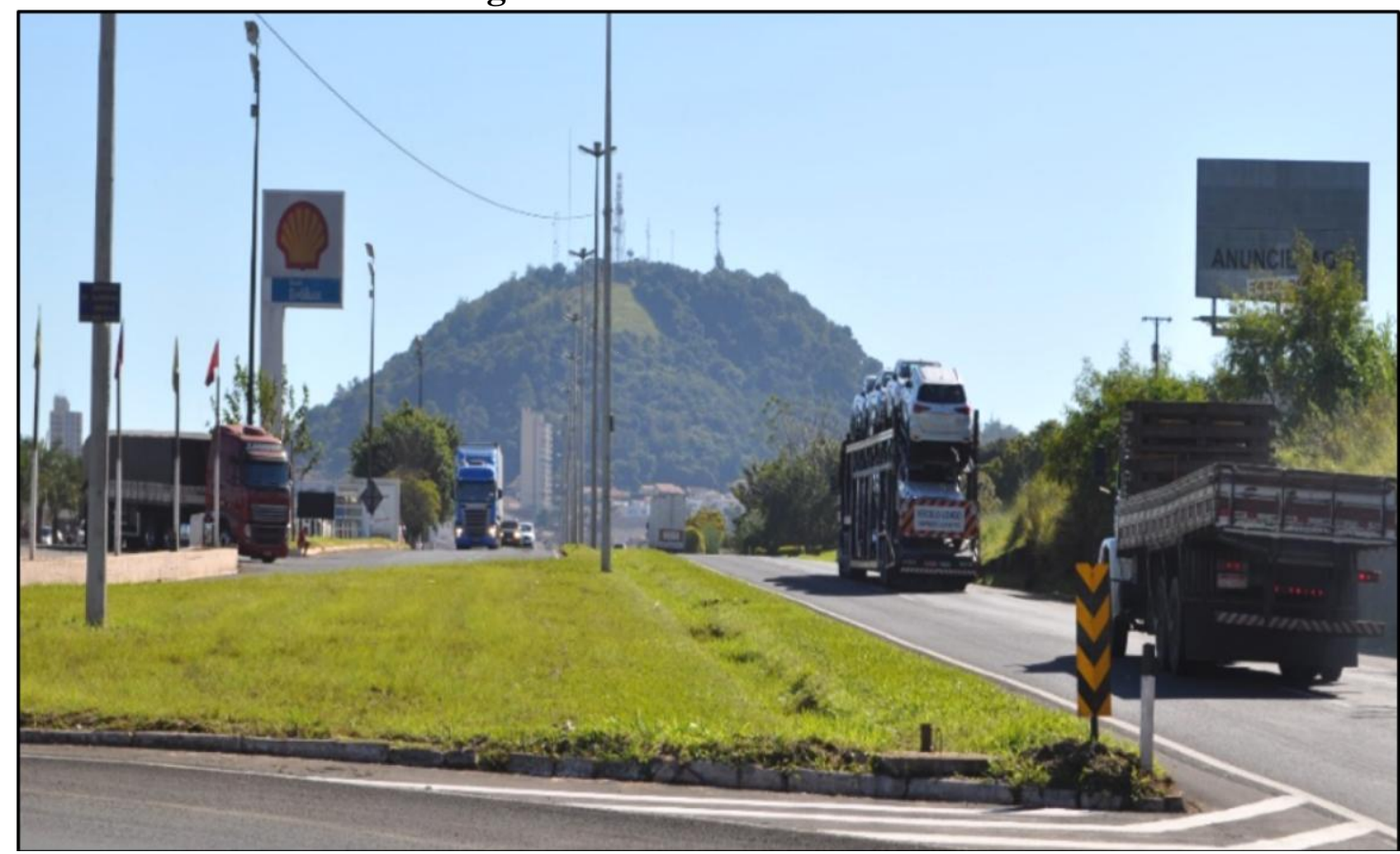

Fonte: Euzemar Florentino Junior (2018).

O morro testemunho é um corpo sedimentar recoberto por camada resistente, o que explica a sua permanência na paisagem, em relação às rochas que o circundavam e que foram erodidas. Para quem passa por este município através da BR-153 ou mesmo para quem chega pela PR-349 é impossível não visualizar essa formação rochosa e mesmo admirar a sua beleza.

\section{Ponto 5: Intemperismo biológico "raizes” em basalto da Formação Serra Geral}

O ponto 5 , localiza-se nas coordenadas $23^{\circ} 17^{\prime} 2.57^{\prime \prime} \mathrm{S}$ de latitude e $50^{\circ} 4^{\prime} 8.77^{\prime \prime O}$ de longitude, na área urbana do município de Santo Antônio da Platina, em uma estrada de terra 
que liga o centro da cidade a um loteamento que está sendo aberto na face sudeste do "Morro do Binda".

Neste local (Figura 12), pode-se visualizar a ocorrência ou o resultado dos processos de intemperismo físico, químico e biológico, com especial destaque para o intemperismo biológico $^{18}$. Assim, a ação da umidade, dos musgos e liquens e das raízes das árvores geram resultados surpreendentes nas rochas expostas no corte da estrada.

Figura 12 - Ponto 5: Intemperismo em rocha basáltica em corte de estrada.

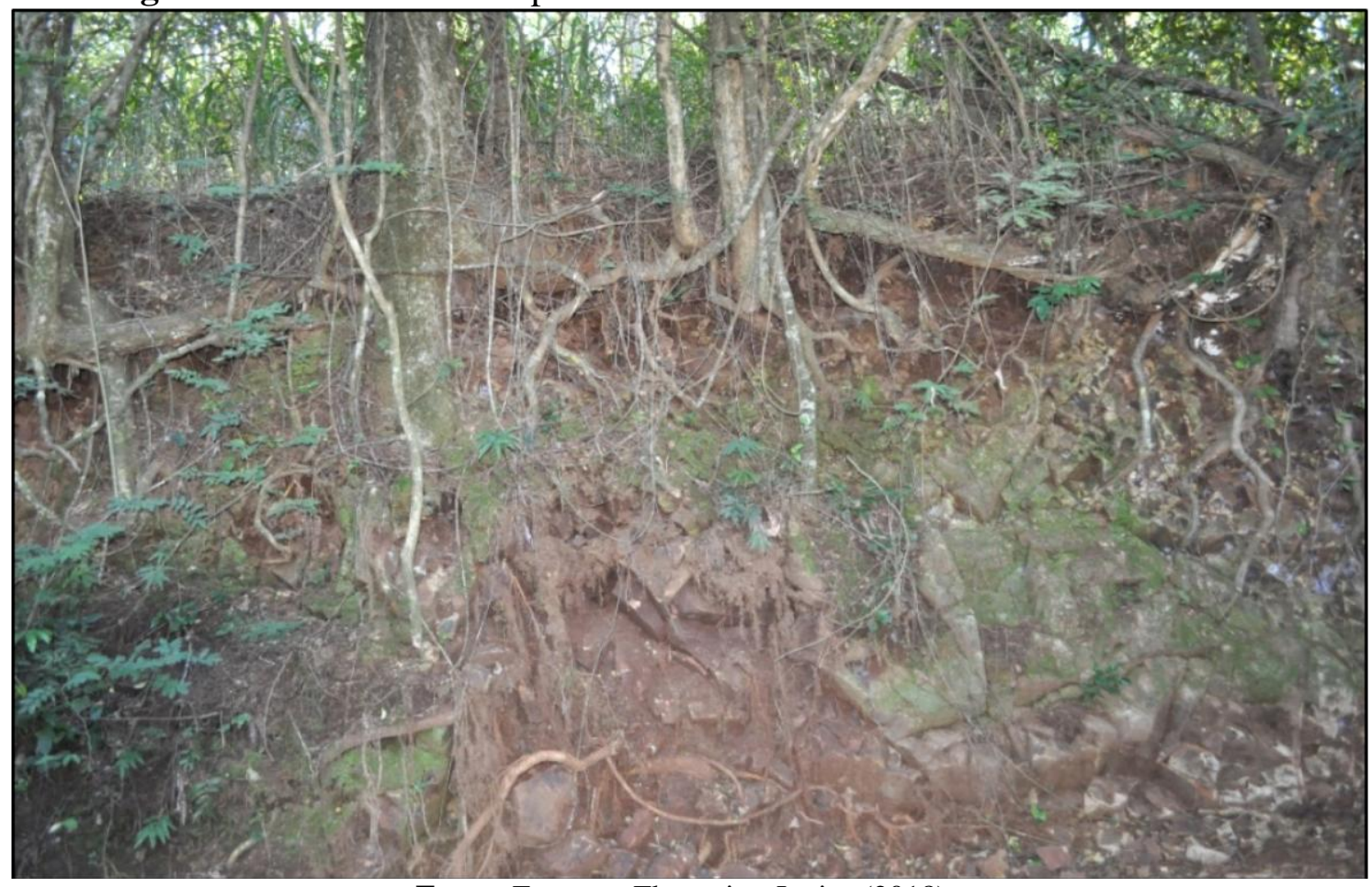

Fonte: Euzemar Florentino Junior (2018).

É possível também visualizar a ação das águas como meio de erosão e transporte de materiais, além de afloramentos de basaltos que apresentam esfoliação esferoidal ${ }^{19}$ impressionantes.

Ponto 6: Paisagem evidenciando relevo de cuesta

O ponto $\mathrm{n}^{\circ} 6$, situa-se nas coordenadas $23^{\circ} 17^{\prime} 02^{\prime}$ 'S latitude e de $50^{\circ} 04^{\prime} 08^{\prime \prime} \mathrm{O}$ longitude, na área urbana do município de estudo, na porção superior do "Morro do Binda".

\footnotetext{
${ }^{18} \mathrm{O}$ intemperismo biológico ocorre pela ação dos organismos vivos em associação com processos físicos e/ou químicos. Desta forma, as raízes das plantas, por exemplo, auxiliam a fragmentação mecânica das rochas, enquanto algumas substâncias químicas produzidas pela vegetação contribuem para a sua decomposição (SUGUIO, 1998).

19 Esfoliação esferoidal é um "Processo de alteração intempérica desenvolvendo formas arredondadas concêntricas que se assemelham a cascas de cebolas [...] (CPRM, 2018).
} 
A partir deste ponto (Figura 13), olhando na direção sudoeste pode-se visualizar um conjunto de cuestas próximas ao Rio das Cinzas. Ao olhar-se no sentido nordeste vê-se um front impressionante o qual é vencido pela rodovia BR-153 que segue em direção a Ourinhos no estado de São Paulo.

Figura 13 - Ponto 6: Relevo de Cuesta.

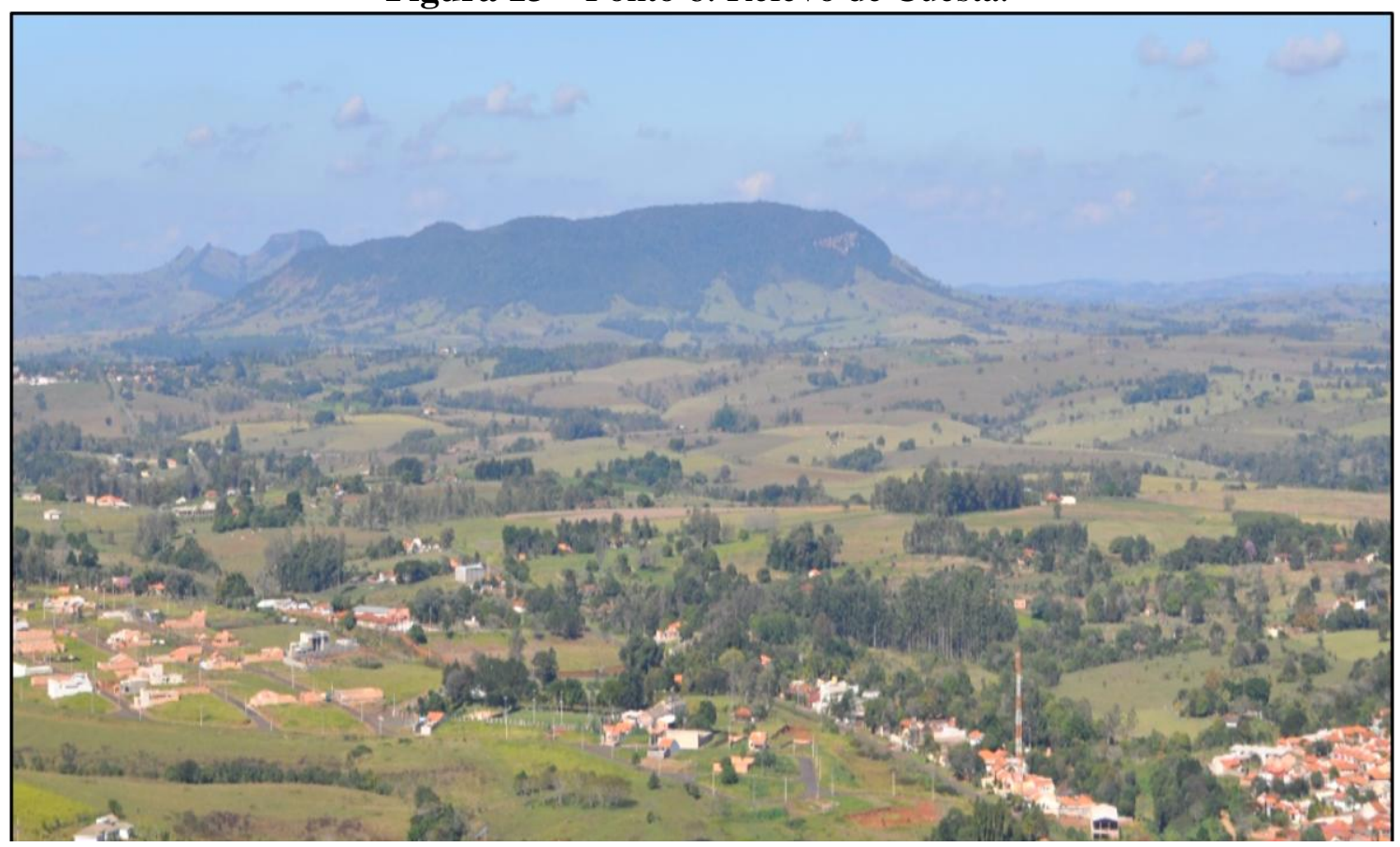

Fonte: Euzemar Florentino Junior (2018).

O conjunto de formas de relevo de cuesta presentes na região de Santo Antônio da Platina tem relação com a sucessão alternada das camadas com diferentes resistências ao desgaste e que se inclinam numa direção, formando um declive suave de um lado e um corte abrupto de outro. Encontram-se associados a estruturas sedimentares, normalmente, recobertas por estratos basálticos. São formas de relevo típicas das bordas de bacia sedimentar.

Algumas formas de cuesta presentes na região, em função da sua semelhança, podem ser confundidas com relevo do tipo mesa ${ }^{20}$ ou mesetas ${ }^{21}$, porém estas mesetas tem o topo plano, enquanto que as cuestas apresentam inclinação em seu topo, geralmente voltadas para o interior da bacia sedimentar. As cuestas identificadas em Santo Antônio da Platina, aparentemente não seguem o padrão do direcionamento da inclinação, uma vez que estão em

\footnotetext{
${ }^{20}$ Remanescente de uma antiga superfície, cujos terrenos ao redor foram escavados e retirados pela erosão. Sua forma é semelhante a de uma mesa (GUERRA, GUERRA, 2001).

21 "Denominação regional da Espanha Central para os planaltos cuja topografia é acentuadamente plana" (GUERRA; GUERRA, 2001, p. 420).
} 
sentido norte e nordeste, quando "deveriam" estar no sentido oeste ou noroeste, em direção ao centro da bacia sedimentar do Paraná.

\section{Considerações Finais}

Os resultados obtidos através desta pesquisa demonstram que Santo Antônio da Platina apresenta ampla variedade em elementos físico-naturais, com especial destaque para: cabeceiras de drenagem em anfiteatro; morros testemunhos; afloramentos de rochas basálticas da Formação Serra Geral e sedimentares, em especial da Formação Botucatu; anomalias de drenagem e depósitos fluviais no Rio das Cinzas; afloramentos com exemplos da ação dos processos intempéricos em rochas e relevo de cuestas.

Verificou-se também que este município apresenta elevado potencial geoturístico, não apenas por conta de sua Geodiversidade, mas também, pela presença de infraestruturas turísticas e meios de comunicação.

Desta forma, a elaboração do roteiro geoturístico em Santo Antônio da Platina voltouse à divulgação, valoração e conservação da Geodiversidade local, podendo ser utilizado tanto para a implantação do Geoturismo como de práticas voltadas à educação ambiental.

Destaca-se que, devido ao fato deste município ter uma extensão territorial considerável,aproximadamente $721,625 \mathrm{~km}^{2}$, e em função dos recursos disponíveis para a realização da pesquisa, o roteiro abrangeu apenas uma parcela dos elementos da Geodiversidade local.

Dentre as dificuldades encontradas para a elaboração desta pesquisa, destacam-se: a carência de recursos financeiros disponibilizados pela Universidade e pelos órgãos de fomento à pesquisa, a carência de bibliografias e de dados primários acerca dos aspectos físico-naturais e turísticos do município de estudo, assim como, a distância entre o município de Londrina (PR) e a área de estudo.

Em relação às facilidades encontradas para a realização da pesquisa, podemos citar: a existência de levantamentos sobre os aspectos geológico-geomorfológicos da região de estudo, notadamente os realizados pela Mineropar; a facilidade de acesso aos pontos geoturísticos, principalmente por causa das boas condições das estradas e os instrumentos cedidos pela Universidade Estadual de Londrina para a realização do trabalho de campo, entre eles: GPS e máquina fotográfica. 
Finalmente, sugere-se que a prefeitura municipal de Santo Antônio da Platina firme parceria com pesquisadores, universidades e órgãos de pesquisa que desenvolvam estudos e projetos voltados a Geoconservação e o Geoturismo, contribuindo para a conservação da Geodiversidade local e para a geração de renda para a população do município.

\section{Referências}

ALMEIDA, F. F. M.; MELO, M. S. A. Bacia do Paraná e o vulcanismo mesozóico. In: INSTITUTO DE PESQUISAS TECNOLÓGICAS DO ESTADO DE SÃO PAULO IPT. Mapa Geológico do Estado de São Paulo, São Paulo: IPT, 1981, v.1, p.46-81. Escala 1: 500.000.

ANDRADE. J.V. Turismo fundamentos e dimensões. São Paulo: Ática, 1995.

ANDREIS, R. R.; CARVALHO, I. S. A Formação Corumbataí (Permiano Superior Triássico Inferior, Bacia do Paraná) na pedreira de Pau Preto, Município de Taguaí, São Paulo, Brasil: análise paleoambiental e das pegadas fósseis. Revista Brasileira de Paleontologia, v. 2, 2001, p. $33-46$.

ANDRETTA, V.; KARNOPP, P. K. F. ; MACEDO, R. L. G. ; VITORINO, M. R.; MACEDO, S. B. ; VENTURIN, N. . O lúdico através de dinâmicas vivenciadas na natureza. In: Congresso Nacional de Ecoturismo, 2007, Itatiaia. Anais do Congresso Nacional de Ecoturismo. Itatiaia: Phsys, 2007.

AUGUSTO, W. C. B.; DEL LAMA, E. A. Roteiro geoturístico no centro da cidade de São Paulo. Terrae Didatica (Impresso), v. 7, p. 29-40, 2011.

BAIXARMAPAS. Estado do Paraná. Disponível em: < http://www.baixarmapas.com.br/wp-content/uploads/mapa-estado-parana-mesorregioes.png> Acesso em: 01 ago. 2018.

BRILHA, J. Patrimônio Geológico e Geoconservação: A conservação da Natureza na sua vertente geológica. Braga: Palimage Editores, 2005.

CPRM.

Esfoliação

Esferoidal.

<http://sigep.cprm.gov.br/glossario/verbete/esfoliacao_esferoidal.htm>. Acessado em 17 julho de 2018.

FELIZOLA, H. F.; BOULET, B. Evolution and opening of closed depressions devoloped in a quartz-kaolinitic sedimentary substratum at Taubaté basin (São Paulo, Brazil), and analogy to the slope evolution. Geomorphology, v.16, 1996, p. 77-86.

FERNANDES, L. A.; COIMBRA, A. M., 1993. Registros de episódios sísmicos na parte superior da Formação Rio do Rasto no Paraná. In: Anais do $3^{\circ}$ Simpósio de Geologia do Sudeste, Rio de Janeiro: UERJ/PETROBRÁS/CPRM/DRM/SBG, 1993, p. 271-275. 
FLORENTINO JR., E. Estudo do potencial geológico-geomorfológico na região de Ribeirão Claro/Jacarezinho (PR) para a proposição de um georoteiro aplicado ao ensino de Geografia. 2014.110f. Trabalho de conclusão de curso (Bacharelado em Geografia) Faculdade de Geografia, Universidade Estadual Paulista, Ourinhos.

FLORENTINO JUNIOR, E.; MACHADO, G. . Santo Antônio da Platina (PR): uma análise dos potenciais geoturísticos. In: XII Encontro Nacional da ANPEGE/ENANPEGE, 2017, Porto Alegre/RS. Anais do XII Encontro Nacional da ANPEGE. Porto Alegre/RS: ENANPEGE, 2017. v. 1. p. 9903-9913.

GUERRA, A.T.; GUERRA, A.J.T. Novo dicionário geológico-geomorfológico. $2^{\mathrm{a}}$ ed. Rio de Janeiro: Bertrand Brasil, 2001.

GUIMARÃES, G. B.; LICCARDO, A.; PIEKARZ, G. F. A valorização cultural do patrimônio geológico-mineiro do Paraná. Boletim Paranaense de Geociências, v. 70, p. 41$52,2013$.

INSTITUTO PARANAENSE DE DESENVOLVIMENTO ECONÔMICO E SOCIAL (IPARDES). Leituras regionais: mesorregião geográfica Norte Pioneiro paranaense. Curitiba: BRDE, 2004.

KLIMANATURALI. $\quad$ Floresta $\quad$ Estacional Semidecidual. http://www.klimanaturali.org/2012/11/floresta-estacional-semidecidual.html> Acesso em: 08 mai. 2018.

MACHADO, M.B.; MOURA, J.R.S. A Geomorfologia e a sedimentação Quaternária no médio vale do rio Casca, MG. Anais do Congresso Brasileiro de Geologia, Salvador, vol. 4, 1982, p. 1433-1441.

MILANI, E.J.; MELO, G.H.G.; SOUZA, P.A.; FERNANDES, L.A.; FRANÇA, A.B. Bacia do Paraná. Boletim de Geociências da Petrobras, Rio de Janeiro, v. 15, n. 2, p. 265-287, maio/nov. 2007.

MINEROPAR. Potencialidades e fragilidades das rochas do Estado do Paraná. Curitiba: MINEROPAR, 2006.

MINISTÉRIO DO TURISMO. Dados e Fatos. Disponível em: < http://www.dadosefatos.turismo.gov.br/gloss\%C3\%A1rio-do-turismo/890-i.html> Acesso em: 10 de set. de 2017.

MUCIVUNA, V. C.; DEL LAMA, E. A.; GARCIA, M. G. M. Proposta de roteiros geoturísticos para as fortificações do litoral paulista. GEONOMOS, v. 24, p. 287-292, 2016.

NASCIMENTO, M. A. L.; RUCHKYS, Ú.A.; MANTESSO NETO, V. Geodiversidade, Geoconservação e Geoturismo: trinômio importante para a proteção do patrimônio geológico. São Paulo: Sociedade Brasileira de Geologia, 2008. 
PREFEITURA MUNICIPAL DE SANTO ANTÔNIO DA PLATINA. Pontos Turísticos. Disponível em:

http://santoantoniodaplatina.pr.gov.br/index.php?sessao=b054603368pvb0\&id=197>. Acesso em: 20 abr. 2018.

SANTOS, M.; BATEZELLI, A. ; NUNES, J. O. R. ; LADEIRA, F. S. B. . Seriam, os rios, 'nômades'? Tectônica extensional, paleocanais, avulsão quaternária e migração na bacia do rio das Cinzas, Norte do Paraná. In: XI Sinageo - Simpósio Nacional de Geomorfologia, 2016, Maringá - PR. Anais do XI Sinageo. Maringá: UEM, 2016.

SUGUIO, K. Dicionário de geologia sedimentar e áreas afins. Rio de Janeiro: Bertrand Brasil, 1998.

TROPPMAIR, H. Biogeografia e Meio Ambiente. 8 ed. Rio Claro: Divida, 2008.

VIERO, A. C.; SILVA, D.R.A. da (Org.). Geodiversidade do Estado do Rio Grande do Sul. Porto Alegre: CPRM, 2010.

WWF. O que são matas ciliares? Disponível em: < https://www.wwf.org.br/natureza_brasileira/questoes_ambientais/matas_ciliares/> Acesso em: 16 jul. 2018. 